\title{
How are endemic and widely distributed bromeliads responding to warming temperatures? A case study in a Brazilian hotspot ${ }^{\text {is }}$
}

\author{
Cleber Juliano Neves Chaves ${ }^{*, 1}$, Bárbara Simões Santos Leal ${ }^{1}$, José Pires de Lemos-Filho* \\ Departamento de Botânica, Instituto de Ciências Biológicas, Universidade Federal de Minas Gerais, Belo Horizonte, Brazil
}

\section{A R T I C L E I N F O}

\section{Article history:}

Received 26 December 2016

Received in revised form 10 May 2017

Accepted 13 May 2017

Edited by P. Morellato

Available online 25 May 2017

\section{Keywords:}

Thermal tolerance

Climate change

Bromeliaceae

Species range

CAM

$\mathrm{C}_{3}$

\begin{abstract}
A B S T R A C T
The increase in mean global temperature is causing extensive changes in ecosystems. However, little is yet known about the heat tolerance of neotropical plant species. Here, we investigate heat tolerance variation in both restricted and widely distributed bromeliad species co-occurring in campo rupestre, a megadiverse ecosystem in central and eastern Brazil. We determined the heat tolerance of the photosynthetic apparatus using chlorophyll fluorescence measurements to test if the endemic species Vriesea minarum is more heat sensitive than two widely distributed species, Vriesea bituminosa and Aechmea nudicaulis. Furthermore, we tested if the distinct photosynthetic metabolisms of the species, sun exposure, and rainfall seasonality of campo rupestre influence this outcome. Our results show that, contrary to our expectations, the endemic campo rupestre species did not show the greatest heat sensitivity, but did have one of the lowest heat tolerance plasticities. The CAM bromeliad A. nudicaulis was more heat tolerant than the other bromeliad species, but both heat tolerance and its plasticity are highly affected by sun exposure and the rainfall seasonality of campo rupestre. The low values and plasticity of V. minarum thermal tolerance could indicate that the threat of global warming could be greater for this campo rupestre endemic species. Our results also indicate that heat tolerance, especially the ability to withstand stressful temperatures for a long time, is an important parameter that differentiates the ecological strategies of these bromeliads species.
\end{abstract}

(c) 2017 Elsevier GmbH. All rights reserved.

\section{Introduction}

Temperatures below $10^{\circ} \mathrm{C}$ and above $35^{\circ} \mathrm{C}$ can cause permanent damages to most plants (Went, 1953; Berry and Bjorkman, 1980). The rise in the mean global temperature observed over the last century (IPCC, 2007) and an increase of ca. $2^{\circ} \mathrm{C}$ in the maximum global temperature during the first half of the 21 st century (IPCC, 2012) are causing deep alterations to ecosystems, from damages to the chloroplast integrity of plants (Berry and Bjorkman, 1980; Yamane et al., 2000; Hüve et al., 2011; Zhang et al., 2012) to mass extinctions (e.g. Crowley and North, 1987; Malcolm et al., 2006; Carpenter et al., 2008; Weigelt et al., 2016). But prior to going extinct, species may respond to climate change by altering their phenology and other physiological responses (i.e. phenotypic

\footnotetext{
is This article is part of a special issue entitled Plant life in campo rupestre: new lessons from an ancient biodiversity hotspot published at the journal FLORA 238C.

* Corresponding authors.

E-mail addresses: cleberchaves@gmail.com (C.J.N. Chaves),

bssleal@yahoo.com.br (B.S.S. Leal), lemos@icb.ufmg.br (J.P.d. Lemos-Filho).

1 Departamento de Ecologia, Instituto de Biociências, Universidade Estadual Paulista, São Paulo, Rio Claro, Brazil.
}

plasticity); developing new evolutionary strategies; changing their abundance and inter-specific interactions; and shifting their distribution (Holt, 1990; Parmesan, 2006; Blois et al., 2013; IPCC, 2014; Parmesan and Hanley, 2015). Studies have suggested, for instance, that some species have become restricted to refuges (see Rull, 2009; Stewart et al., 2010), shifting their ranges poleward and toward higher elevations due to the warming temperatures since the last glacial maximum (LGM; e.g., Parmesan and Yohe, 2003; Root et al., 2003; Parmesan, 2006; Colwell et al., 2008; Rosenzweig et al., 2008; Chen et al., 2011; Bässler et al., 2013; Pecl et al., 2017). Thus, species currently restricted to interglacial refuges may be more sensitive to warming temperatures than widely distributed species.

Due to its past climatic stability, the campo rupestre ecosystem represents an example of interglacial refuge in the Neotropics (Bonatelli et al., 2014; Barbosa et al., 2015). This vegetation complex is endemic to Brazil, and it is usually restricted to altitudes from 900 to over 2,000 ma.s.l., forming a mosaic archipelago-like system on low water-holding rocks of mountaintops surrounded by lowlands (Alves et al., 2014; Silveira et al., 2016). Studies have shown that campo rupestre is probably the most ancient open vegetation in eastern South America, comprising a great diversity and rate of endemism (Alves et al., 2014; Silveira et al., 2016). Nevertheless, recent studies indicate that campo rupestre vegetation could lose 
from 44\% (Bitencourt et al., 2016) to 95\% (Fernandes et al., 2012) of its current area and about $25 \%$ of its angiosperm species due to climate change (Bitencourt et al., 2016). Such reduction represents the extinction of more than 400 microendemic plant species which are currently restricted to future unsuitable areas (Bitencourt et al., 2016). Such potential scenario is a consequence of the habitat reduction caused by a warming up to $5^{\circ} \mathrm{C}$ in temperature and an increase in frequency of extremely dry seasons. The low dispersal ability of most endemic species makes them unable to reach other suitable mountains; and their high specialization level make them more sensitive to climate changes (Christensen et al., 2007; Dawson et al., 2011; Bittencourt et al., 2016). Despite these worrying forecasts, little is known about how these endemic species would respond to overcome the warming temperatures.

Bromeliaceae is one of the most representative plant families in campo rupestre and nearly half of the bromeliad species occurring in such environment are endemic (Versieux et al., 2008; Silveira et al., 2016). This family is also one of the best examples of adaptive radiation in the Neotropics (Benzing, 2000; Givnish et al., 2014; Givnish, 2015; Palma-Silva et al., 2016). Crassulacean acid metabolism (CAM), for example, is often noted as a key innovation in the family that allowed the exploitation of arid environments, due to its mechanism that closes the stomata during the daytime and avoids excessive water loss during dry periods (Givnish et al., 2014; Silvestro et al., 2014; Palma-Silva et al., 2016). Global climatic changes may favor species with CAM metabolism, due to their supposed higher thermal tolerance (e.g., Yamada et al., 1996; Weng and Lai, 2005) and the anthropogenic increase of arid areas (Nobel, 1988; Cushman and Borland, 2002; Mercier and Freschi, 2008; Osmond et al., 2008). However, Chaves et al. (2015) showed that the daily organic acid accumulation of CAM plants has a strong negative impact on their thermal tolerance (see also Yamori et al., 2014a, 2014b). Therefore, it remains unclear how these plants will respond to ongoing climate change.

Inferences about potential responses of species to climate change from their current distribution can be a good strategy, since some works report a strong relationship between ecological characteristics and niche projections (e.g. Thuiller et al., 2005; Garcia et al., 2014). Here, we aim to test whether an endemic bromeliad species of campo rupestre is more sensitive to warming temperatures than species with wider distributions. For such, we measured the fluorescence of photosystem II through two methods: ramping and static temperature assays. We also examine whether morphophysiological traits, such as photosynthetic pathways (i.e., CAM and $\mathrm{C}_{3}$ photosynthesis), sun exposure, and the marked rainfall seasonality of the campo rupestre, can bias the outcome. Finally, we test whether heat tolerance and its plasticity can distinguish the ecological strategies of these bromeliads.

\section{Material and methods}

\subsection{Study site and plant species}

This study was carried out in the Piedade Mountains (Serra da Piedade), situated within the over-exploited Iron Quadrangle, in the southern-most section of the core area of the campo rupestre in the Espinhaço Range, Eastern Brazil (Alves et al., 2014; Silveira et al., 2016). The Piedade Mountains have a maximum altitude of 1,746 ma.s.l., and the highest section presents a typical subtropical high-altitude climate, with a well-defined dry season between April and September, and the frequent occurrence of fog (Brandão and Gavilanes, 1990; Marques and Lemos-Filho, 2008). The surroundings (Belo Horizonte city, $40 \mathrm{~km}$ from Serra da Piedade) show a well-defined dry season with an average temperature of $19^{\circ} \mathrm{C}$ and $6 \mathrm{~mm}$ of precipitation in the driest month, and a well-defined

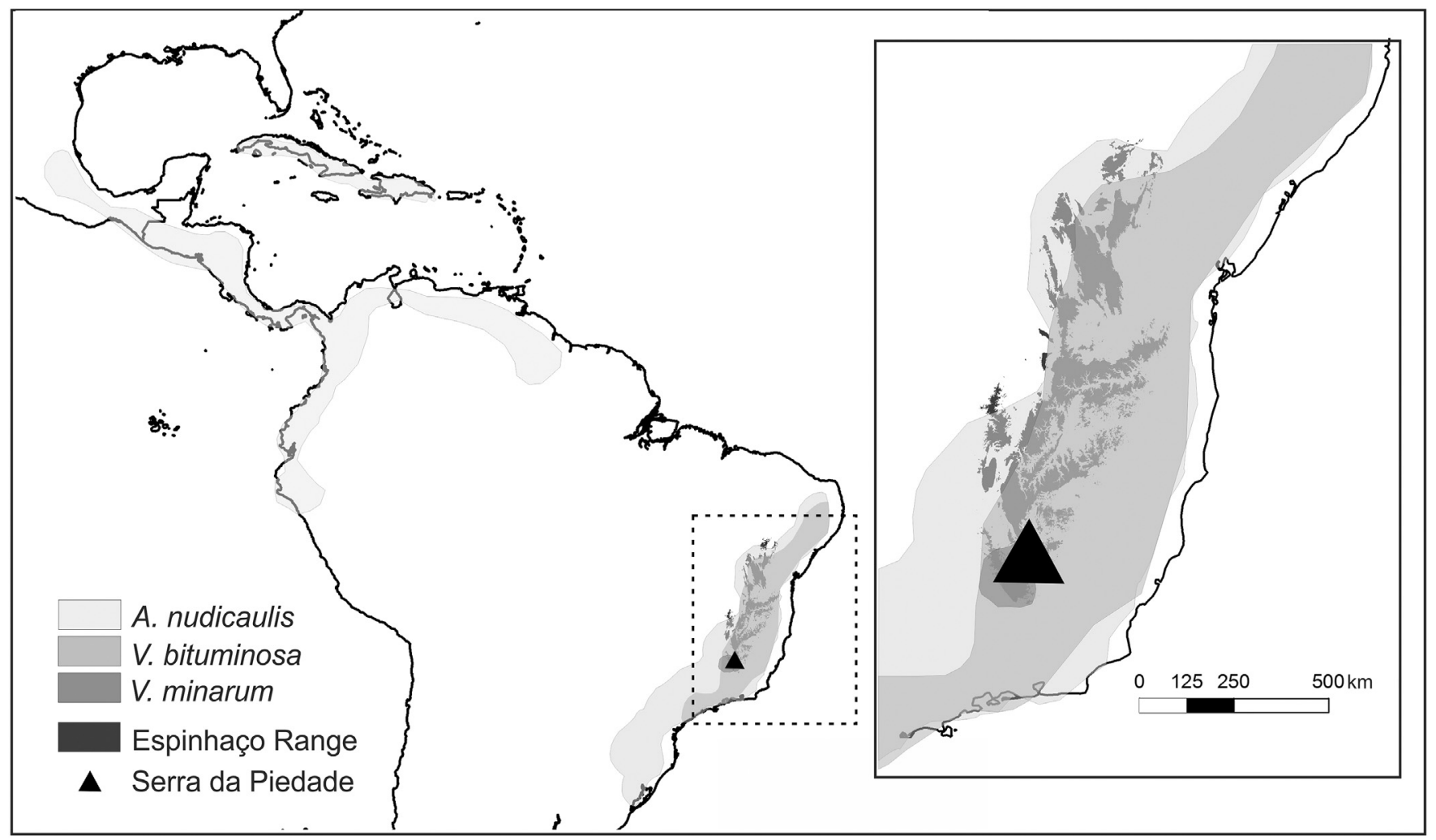

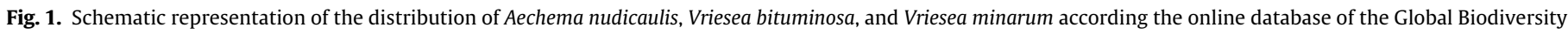
Information Facility (GBIF; via www.gbif.org). 
wet season, with an average temperature of $23^{\circ} \mathrm{C}$ and $322 \mathrm{~mm}$ of total precipitation in average on the wettest month (historical data from January 1990 to December 2016 achieved in the website www.inmet.gov.br). Frosts and temperatures close to $0^{\circ} \mathrm{C}$ are common at the highest altitudes (Brandão and Gavilanes, 1990). Our study area is above 1,400 ma.s.l. and comprises two microenvironments: a xeric zone, highly exposed to sun and winds, characterized by the occurrence of iron-quartzite rock outcrops and herbaceous-shrubby vegetation (hereafter referred to as sunexposed environment); and a shaded zone within an altitudinal cloud forest, characterized by the presence of shrubby and arboreal vegetation and high moisture (hereafter, shaded environment).

Here, we selected three bromeliad species: two $C_{3}$ species, Vriesea minarum L.B. Sm and Vriesea bituminosa Wawra, from the Tillandsioideae subfamily, and a CAM species, Aechmea nudicaulis (L.) Griseb., from the Bromelioideae subfamily. Vriesea minarum is a rupicolous species endemic to the campo rupestre (Fig. 1; Forzza et al., 2012), occurring in sun-exposed environments of the Piedade Mountains. Vriesea bituminosa occurs as a rupicolous or epiphytic bromeliad in sections of forests associated with outcrops in eastern Brazil and in Venezuela (Fig. 1; Coser, 2008; Forzza et al., 2012). At the study site, this species is often found in shaded areas, where we collected all samples. The CAM species, A. nudicaulis, is widely distributed throughout the Neotropics, from Mexico to Peru, the Caribbean, eastern Brazil, and Guyana (Fig. 1; Smith and Downs, 1979). In Brazil, the species occurs in sandy coastal zones, moist forests, rock outcrops in the Atlantic Forest, and campos rupestres (Bert and Luther, 2005). In our study site, A. nudicaulis were sampled in both sun-exposed and shaded environments, designated as "sun-exposed A. nudicaulis" and "shaded A. nudicaulis", respectively.

\subsection{Microclimatic information}

To measure the seasonal climate differences of the study site, we recorded photosynthetic photon flux density (PPFD) and air temperature data from sun-exposed and shaded environments on all sampling days during the dry and rainy seasons (Fig. 2). We also measured relative humidity in the shaded environment and the dry-season surface temperature of a sun-exposed rocky outcrop. All measurements were made using sensors coupled with data loggers (LI-1400, LI-COR Inc. and TD-880, ICEL).

\subsection{Sampling}

We employed two different methods to determine photosynthetic thermal tolerance of the studied species: a ramping assay (under increasing temperatures) and a static assay (under constant high temperature; see following sections). For the ramping assay, we collected $\sim 1.5 \mathrm{~cm}^{2}$ leaf samples from the top (upper third) and basal (bottom third) sections of one young and totally expanded leaf from five individuals of each studied group (sun-exposed $A$. nudicaulis, shaded $A$. nudicaulis, $V$. minarum, and $V$. bituminosa). We sampled these individuals during the dry and rainy seasons, at 08:00 and 15:00, when organic acids reach their maximum and minimum accumulations in $A$. nudicaulis (due to CAM photosynthesis; data not shown). We also sampled the same individuals to determine morphophysiological traits (see section 2.6). For the static assay, we collected $\sim 1.5 \mathrm{~cm}^{2}$ samples from the top and basal leaf regions of five individuals from each studied group during the rainy season, at 15:00; see follow sections).

\subsection{Heat tolerance of photosystem II (PSII): ramping assay}

To determine the thermal tolerance of photosystem II (PsiI) under increasing temperatures (ramping assay), we placed each of
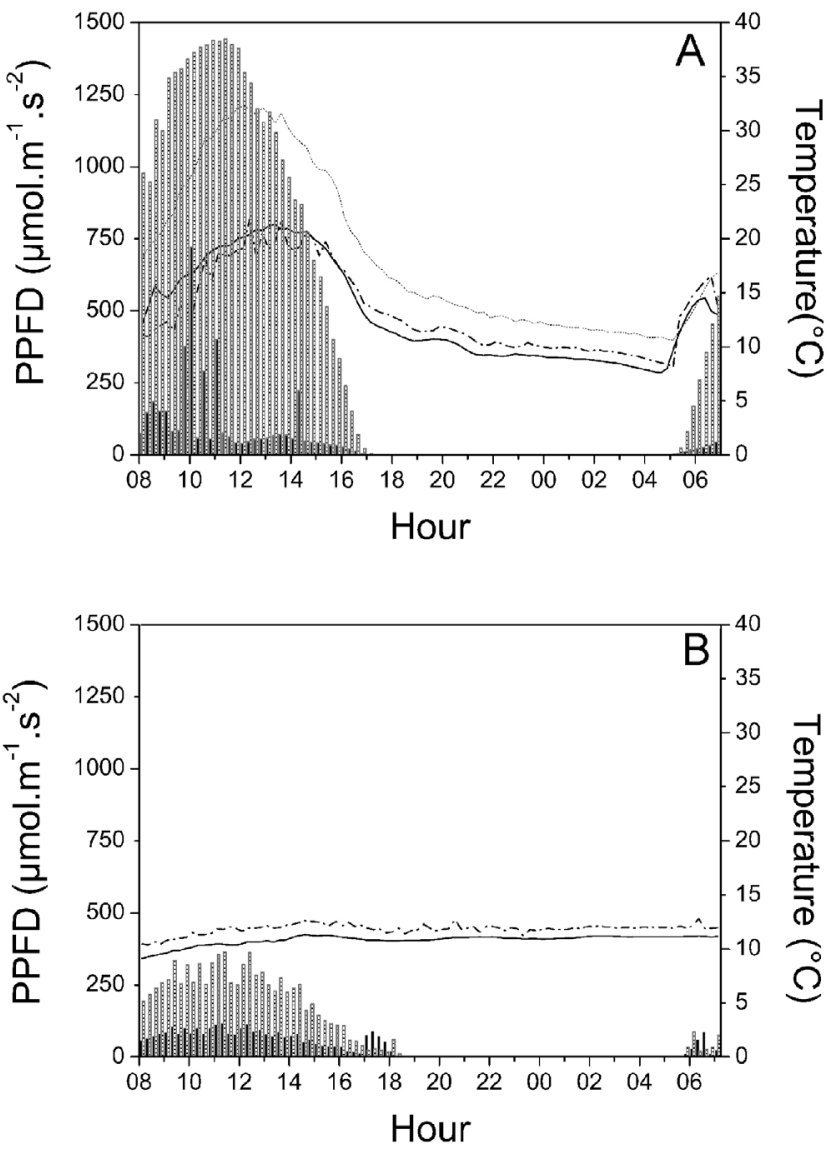

Fig. 2. Photosynthetic photon flux density (PPFD) and average temperature of a day in the dry (A) and rainy seasons (B). Full and dashed bars represent the PPFD of shaded and exposed environments, respectively. Solid and dashed lines represent, respectively, the temperature of shaded and exposed environments. The dotted line, in $\mathrm{A}$, represents the temperature of rock outcrop.

the collected samples in a hermetically sealed plastic bag and kept it under natural light, partially shaded, for $24 \mathrm{~h}$. We proceeded with a thermal tolerance test in the laboratory, using an ex vivo procedure. Previous tests of this procedure have shown that it does not significantly influence the measured potential quantum yield (variable fluorescence/maximum fluorescence; $F_{v} / F_{m}$ ) of the leaves (data not shown). Subsequently, we removed the samples from the plastic bags and kept them in the dark and at room temperature $\left(\sim 25^{\circ} \mathrm{C}\right)$ for $15 \mathrm{~min}$; we then measured the initial $\mathrm{F}_{\mathrm{v}} / \mathrm{F}_{\mathrm{m}}$ using a modulate fluorometer (MINI-PAM, Walz). The thermal tolerance test was conducted as described by Godoy et al. (2011), but using a thermostatic water bath as a heater (214D2, QUIMIS). We sealed the aluminum plate containing the samples with a plastic bag and used a thermocouple linked to a digital thermometer (TD-880, ICEL) to check the temperature of samples. Leaf samples were subjected to increasing temperatures, from $35^{\circ} \mathrm{C}$-the upper limit of the optimal temperature range for most plants (Went, 1953; Berry and Bjorkman, 1980)-to $65^{\circ} \mathrm{C}$, with an average increase of $1{ }^{\circ} \mathrm{C}$ every $3 \mathrm{~min}$. We measured $\mathrm{F}_{\mathrm{v}} / \mathrm{F}_{\mathrm{m}}$ once after every increase of $2{ }^{\circ} \mathrm{C}$. The data were used to determine the critical temperatures that promote a $15 \%\left(\mathrm{~T}_{15}\right)$ and $50 \%\left(\mathrm{~T}_{50}\right)$ reduction of the initial $\mathrm{F}_{\mathrm{v}} / \mathrm{F}_{\mathrm{m}}$, using a sigmoidal equation (Fig. 3A) as described by Knight and Ackerly (2003). This analysis was performed using a purpose-built function in R statistical software version 3.0.1 (see Supplementary Material; R Core Team, 2014). 

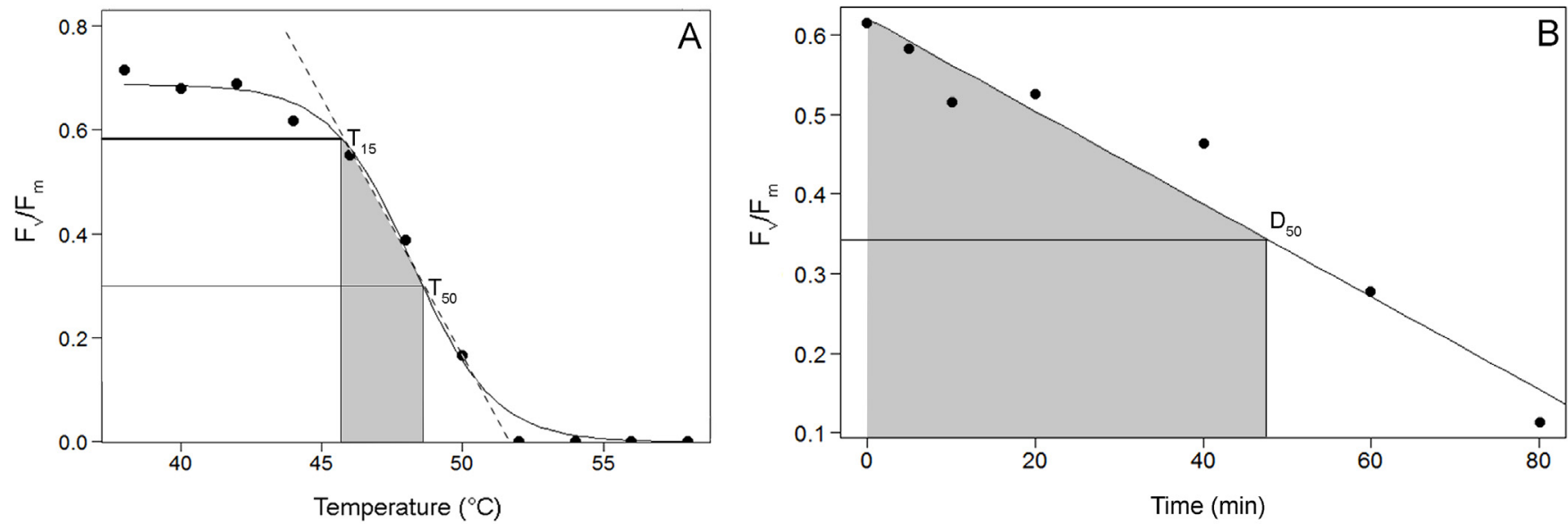

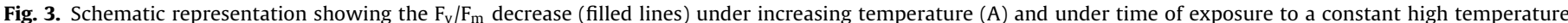

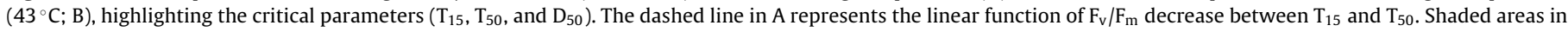
$A$ and $B$ represent, respectively, the temperature differences and the time elapsed between the decay of $15 \%$ and $50 \%$ on initial $\mathrm{F}_{\mathrm{v}} / \mathrm{F}_{\mathrm{m}}$

\subsection{Heat tolerance of PSII: static assay}

To test if the species most tolerant to increasing temperatures is also the most tolerant to constant stressful temperatures, we followed an experimental procedure similar to the one described above, except that the $\mathrm{F}_{\mathrm{v}} / \mathrm{F}_{\mathrm{m}}$ measures were made before immersing the samples in a water bath and again after 1, 5, 10, 20, 40, 60, and $80 \mathrm{~min}$, at a constant temperature of $43^{\circ} \mathrm{C}$ (which represents the average of $\mathrm{T}_{15}$ values obtained in the ramping assay for all the samples of Vriesea species, the less heat tolerant groups; see Table $\mathrm{S} 1)$. We estimated the critical time, in minutes, that would promote a $50 \%$ reduction of the initial $\mathrm{F}_{\mathrm{v}} / \mathrm{F}_{\mathrm{m}}\left(\mathrm{D}_{50}\right)$, using a linear function (Fig. 3B). This analysis was also performed using a purpose-built function in R statistical software version 3.0.1 (see Supplementary Material; R Core Team, 2014).

\subsection{Morphophysiological traits and heat tolerance}

To verify the relationships between heat tolerance and other morpho-physiological traits, and to distinguish the ecological strategies of each experimental group (sun-exposed $A$. nudicaulis, shaded $A$. nudicaulis, V. minarum, and V. bituminosa), we determined the daily variation of titratable acidity (as per Hartsock and Nobel, 1976), succulence index (SI; as per Ogburn and Edwards, 2010, 2012), and relative water content (RWC) of all samples. Moreover, we estimated the stomata and scale densities of the top and basal sections of the leaves from each experimental group. To do this, leaf samples were fixed in FAA50 (Johansen, 1940) and stored in ethanol $70 \%$ for subsequent analysis. The epidermises were excised by immersion in 66\% commercial sodium hypochlorite for three days. We then stained the epidermises with safranin-astra blue (Bukatsch, 1972) and mounted them in Kaiser gelatin (Kraus and Arduin, 1997). The adaxial and abaxial stomata and scales within six $0.06-\mathrm{mm}^{2}$ fields on each sample were counted using a microscope with a camera lucida (Stemi, 2000, Zeiss). We considered the scale density as the sum of both faces of each sample.

To overcome the variability of each physiological trait, we estimated the overall phenotypic plasticity based on the relative distance phenotypic index (RDPI), as described by Valladares et al. (2006). For each experimental group (sun-exposed A. nudicaulis, shaded $A$. nudicaulis, V. minarum, and V. bituminosa), we calculated a combination of the relative distances between the values for these traits for all collection times of day and seasons, generating only one distance value.
Table 1

Means and standard errors of projected $D_{50}$ values of all experimental groups at 15:00 in the rainy season. Same letters represent values statistically equal among all groups.

\begin{tabular}{llll}
\hline Species & Environment & Leaf region & $\mathrm{D}_{50}(\mathrm{~min})$. \\
\hline A. nudicaulis & Sun-exposed & Top & $80.86 \pm 11.8^{\mathrm{b}}$ \\
& & Basal & $103.17 \pm 5.3^{\mathrm{b}}$ \\
& Shaded & Top & $157.87 \pm 17.4^{\mathrm{a}}$ \\
& & Basal & $163.66 \pm 28 .^{\mathrm{a}}$ \\
V. minarum & Sun-exposed & Top & $73.19 \pm 4.8^{\mathrm{b}}$ \\
V. bituminosa & & Basal & $81.56 \pm 2.3^{\mathrm{b}}$ \\
& Shaded & Top & $70.59 \pm 1.8^{\mathrm{b}}$ \\
& & Basal & $73.02 \pm 0.9^{\mathrm{b}}$ \\
\hline
\end{tabular}

\subsection{Statistical analysis}

We performed linear fixed-effect models (LMEs) to test whether the variation in thermal tolerance $\left(\mathrm{T}_{50}, \mathrm{D}_{50}\right.$, and $\mathrm{RDPI} \mathrm{T}_{50}$ values) is associated with the measured morphophysiological traits, and whether thermal tolerance and the morphophysiological traits are related to each other, according Fig. 4A and 4B, respectively. We used the explanatory variables as fixed effects, and individual labels and their leaf regions as random variables. We tested the significance of the models through an analysis of variance (ANOVA), sequentially removing all non-significant variables $(p>0.05)$ with the greatest $p$-values. To test if the plants with the highest thermal tolerance to increasing temperature are also the most thermal tolerant to static stressful temperatures, and to test whether both assays are related, we performed a simple regression between $T_{50}$ and $\mathrm{D}_{50}$ values of all studied groups.

Finally, we performed a canonical discriminant analysis (CDA) followed by general linear models (GLM; see Fig. S1) to evaluate whether thermal tolerance, together with the measured morphophysiological variables, could discriminate the ecological strategies of each species. All statistical analyses were performed with the R packages "nlme", "candisc", and "glmulti" (Wagenmakers and Farrell, 2004; Friendly, 2007; Kenny and Hoyt, 2009).

\section{Results}

\subsection{Heat tolerance of PSII}

Generally, shaded Aechmea nudicaulis and Vriesea bituminosa individuals showed the highest and the lowest heat tolerances, respectively, under both ramping and static thermal tolerance assays (Table 1, Fig. 4, and Tables S1 and S2). Considering the mean 

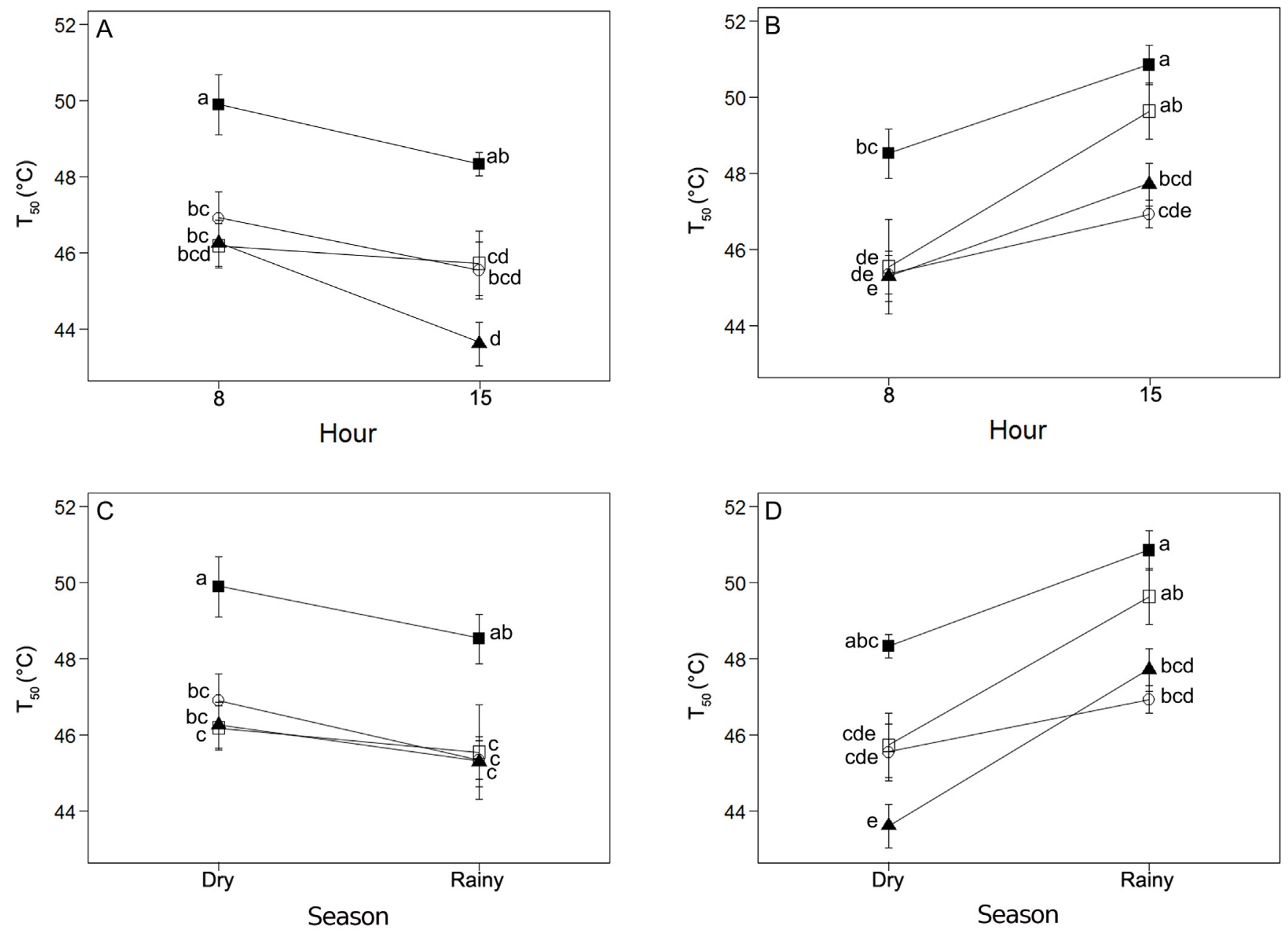



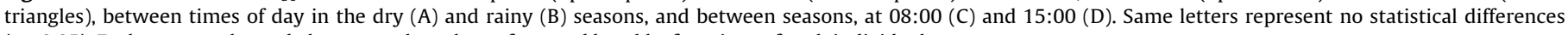
$(p>0.05)$. Each average showed also group the values of top and basal leaf sections of each individual.

of the $T_{50}$ values of all studied groups, we found an interaction among day times and seasons, with greater values at 15:00 in the rainy season and lower values at 15:00 in the dry season (Fig. 4 and Table S1). In the ramping assay performed in the morning, as well as in the static assay, we detected a significantly higher thermal tolerance in shaded $A$. nudicaulis than in sun-exposed plants, which had a thermal tolerance similar to that of Vriesea species (Tables 1, and $\mathrm{S} 1$ ). No significant differences were detected between leaf regions $(p>0.05$; Table 1$)$. We observed directly proportional relationships between $\mathrm{T}_{50}$ and $\mathrm{D}_{50}$ (Fig. 5).

\subsection{Morphophysiological traits and heat tolerance}

The relationships between heat tolerance and morphophysiological variables were significant only for titratable acidity of the basal leaf regions of $A$. nudicaulis sampled in the rainy season. Titratable acidity was inversely proportional to the $\mathrm{T}_{50}$ values (Fig. 6). Regarding the plasticity of morphophysiological traits, sun-exposed A. nudicaulis showed some of the greatest significant values for most of them, except for Titratable acidity and SI in the top and basal leaf regions, respectively (Table 2). In these cases, shaded $A$. nudicaulis was the most plastic. For most of the other cases, shaded $A$. nudicaulis was, together with $V$. minarum, the less plastic group (Table 2).

The top of sun-exposed A. nudicaulis leaves had the greatest daily variation of titratable acidity $\left(\Delta \mathrm{H}^{+}\right.$; Table S2). Their SI val-

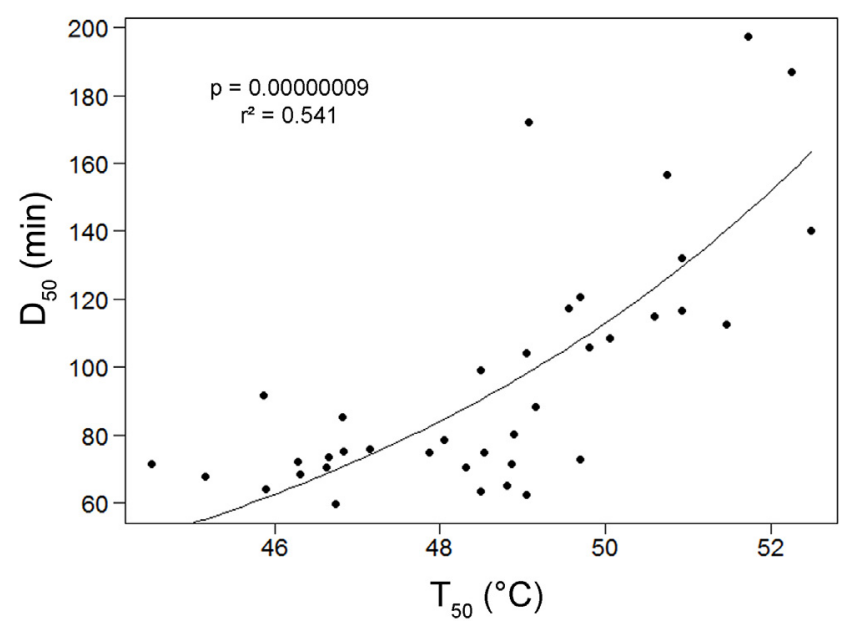

Fig. 5. Exponential relationship between $T_{50}$ (ramping assay) and $D_{50}$ (static assay) values of all studied groups obtained during the rainy season at 15:00.

ues, however, were not statistically distinct from the other studied groups (Table S2). For stomata density, V. minarum and V. bituminosa had, respectively, the lowest and the highest absolute values among the top regions of the leaves (Table S3). For scale density, $V$. minarum and V. bituminosa had, respectively, the lowest and the 


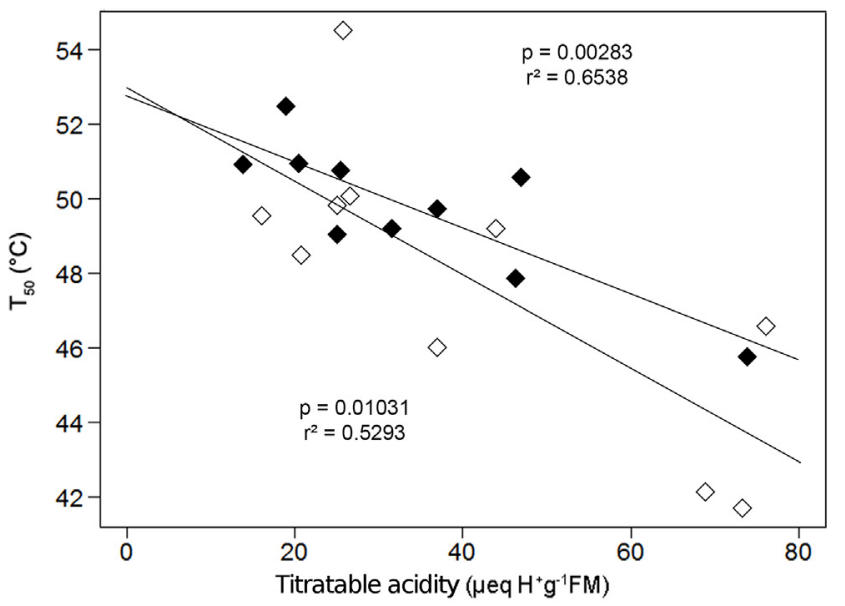

Fig. 6. Negative relationships between $T_{50}$ and titratable acidity in basal region of sun-exposed (open diamond) and shaded (closed diamond) A. nudicaulis.

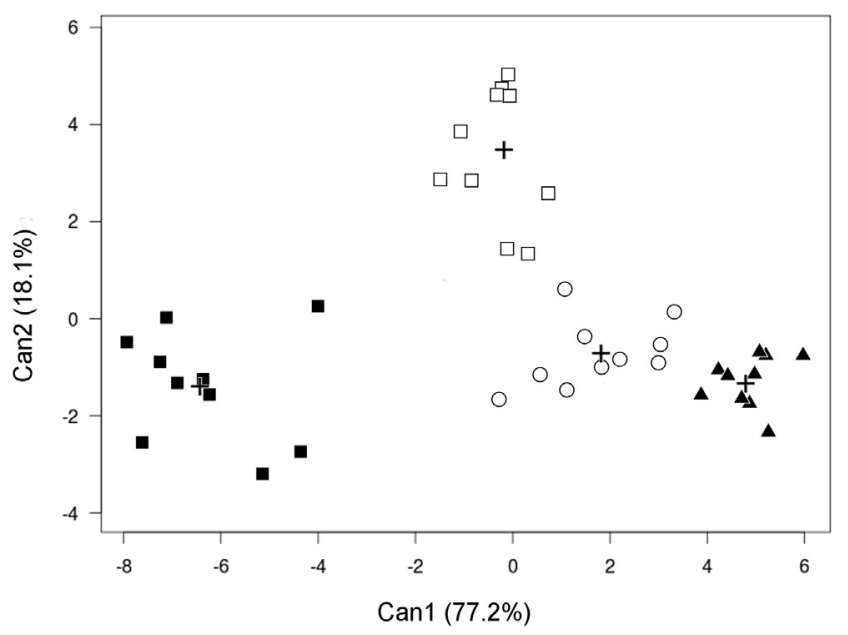

Fig. 7. Biplot representation of the scores on the first two axes of the canonical discriminant analysis for 13 morphophysiological variables of sun-exposed (open squares) and shaded (closed squares) A. nudicaulis, V. minarum (open circles), and $V$. bituminosa (closed triangles). The centroids of each group are represented by a cross.

highest absolute values in the basal regions of the leaves (Table S3). However, stomata and scale density of $C_{3}$ species were not statistically distinct from those of $A$. nudicaulis (Table S3).

The ecological strategies of each experimental group (sunexposed $A$. nudicaulis, shaded $A$. nudicaulis, $V$. minarum, and $V$. bituminosa) were clearly discriminated by CDA analysis (Fig. 7). The first canonical axis accounted for $77.2 \%$ of trait variation and discriminated almost all studied groups (Fig. 7). This axis grouped the variation of mainly SI, $\mathrm{D}_{50}$, and the RDPI of titratable acidity (Table
Table 3

Results of $\mathrm{AIC}_{i}$ (Akaike criterion for model $i$ ), $\Delta_{i}$ (AIC) $\left(\mathrm{AIC}_{i}-\right.$ minAIC), and $w_{i}$ (AIC) (rounded Akaike weights) for all competing models. Bold rows indicate the best fit models, based on $\Delta \mathrm{i}(\mathrm{AIC})<2.0$.

\begin{tabular}{|c|c|c|c|}
\hline Model & $\mathrm{AIC}_{\mathrm{i}}$ & $\Delta_{\mathrm{i}}(\mathrm{AIC})$ & $w_{\mathrm{i}}(\mathrm{AIC})$ \\
\hline D50 + RDPI_acidity + acidity + RDPI_SI & 18.280 & 0.000 & $5.26 \mathrm{E}-001$ \\
\hline SI + D50 + RDPI_acidity + acidity + RDPI_SI & 19.387 & 1.108 & 3.02E-001 \\
\hline D50 + RDPI_acidity + acidity & 21.997 & 3.718 & $8.20 \mathrm{E}-002$ \\
\hline SI + D50 + RDPI_acidity + acidity & 23.303 & 5.024 & 4.27E-002 \\
\hline SI + D50 + acidity + RDPI_SI & 24.089 & 5.809 & $2.88 \mathrm{E}-002$ \\
\hline RDPI_acidity + acidity + RDPI_SI & 28.013 & 9.734 & $4.05 \mathrm{E}-003$ \\
\hline D50 + acidity + RDPI_SI & 28.551 & 10.272 & $3.09 \mathrm{E}-003$ \\
\hline SI + D50 + acidity & 28.907 & 10.627 & $2.59 \mathrm{E}-003$ \\
\hline RDPI_acidity + acidity & 29.038 & 10.759 & $2.43 \mathrm{E}-003$ \\
\hline SI + RDPI_acidity + acidity + RDPI_SI & 30.006 & 11.726 & $1.50 \mathrm{E}-003$ \\
\hline acidity + RDPI_SI & 30.797 & 12.518 & $1.01 \mathrm{E}-003$ \\
\hline D50 + acidity & 30.927 & 12.647 & $9.43 \mathrm{E}-004$ \\
\hline SI + RDPI_acidity + acidity & 31.025 & 12.745 & $8.98 \mathrm{E}-004$ \\
\hline SI + acidity + RDPI_SI & 31.161 & 12.881 & 8.39E-004 \\
\hline acidity & 32.549 & 14.269 & 4.19E-004 \\
\hline SI + acidity & 33.985 & 15.705 & $2.05 \mathrm{E}-004$ \\
\hline SI + D50 + RDPI_acidity + RDPI_SI & 39.168 & 20.888 & $1.53 \mathrm{E}-005$ \\
\hline SI + D50 + RDPI_SI & 39.755 & 21.476 & $1.14 \mathrm{E}-005$ \\
\hline SI + D50 + RDPI_acidity & 39.772 & 21.492 & $1.13 \mathrm{E}-005$ \\
\hline SI + RDPI_SI & 41.875 & 23.596 & $3.96 \mathrm{E}-006$ \\
\hline $\mathrm{SI}+\mathrm{D} 50$ & 43.112 & 24.833 & $2.13 \mathrm{E}-006$ \\
\hline SI + RDPI_acidity + RDPI_SI & 43.451 & 25.172 & $1.80 \mathrm{E}-006$ \\
\hline D50 + RDPI_acidity & 43.477 & 25.198 & $1.78 \mathrm{E}-006$ \\
\hline D50 + RDPI_acidity + RDPI_SI & 44.236 & 25.956 & $1.22 \mathrm{E}-006$ \\
\hline RDPI_acidity & 44.839 & 26.559 & 8.99E-007 \\
\hline RDPI_acidity + RDPI_SI & 45.042 & 26.763 & $8.12 \mathrm{E}-007$ \\
\hline SI & 45.116 & 26.836 & 7.83E-007 \\
\hline SI + RDPI_acidity & 45.275 & 26.995 & $7.23 \mathrm{E}-007$ \\
\hline RDPI_SI & 46.300 & 28.020 & 4.33E-007 \\
\hline NULL & 46.987 & 28.707 & 3.07E-007 \\
\hline D50 + RDPI_SI & 48.089 & 29.810 & $1.77 \mathrm{E}-007$ \\
\hline D50 & 48.695 & 30.415 & $1.31 \mathrm{E}-007$ \\
\hline
\end{tabular}

S4). The second canonical axis - most associated with variation of titratable acidity, $\mathrm{D}_{50}$ and the RDPI of SI - accounted for $18.1 \%$ of the trait variation (Table S4) and differentiated sun-exposed A. nudicaulis from the other groups (Fig. 7). The best model to describe the variances of discriminated functional groups (based on $\Delta$ AIC $<2.0$ ) included the average of $D_{50}$, the mean and RDPI of titratable acidity, and the RDPI of SI (Table 3).

\section{Discussion}

Our results did not corroborate the hypothesis that the bromeliad species restricted to the campo rupestre, Vriesea minarum, is more heat sensitive than the other studied species. Instead, we demonstrated that its heat tolerance was similar to the individuals of the most widely distributed species, Aechema nudicaulis, growing under the same conditions of $V$. minarum. Despite this result, $V$. minarum showed a low thermal tolerance plasticity that was statistically equal to those of shaded individuals of A. nudicaulis. On the other hand, the low thermal tolerance and the plasticity of $V$. minarum indicate a great level of specializa-

Table 2

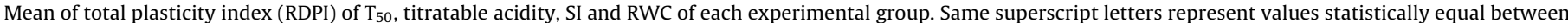
all experimental groups, for each leaf region. Asterisks represent differences statistically significant $(p<0.05)$ between leaf regions.

\begin{tabular}{|c|c|c|c|c|c|}
\hline Parameter measured & Leaf region & Sun-exposed A. nudicaulis & Shaded A. nudicaulis & V. minarum & V. bituminosa \\
\hline \multirow[t]{2}{*}{$\mathrm{T}_{50}$} & Top & $0.031^{\mathrm{a}}$ & $0.020^{c}$ & $0.022^{\mathrm{bc}}$ & $0.026^{\mathrm{b}}$ \\
\hline & Basal & $0.038^{a}$ & $0.024^{\mathrm{c}}$ & $0.021^{\mathrm{c}}$ & $0.031^{\mathrm{b}}$ \\
\hline \multirow[t]{2}{*}{ Titratable acidity } & Top & $0.219^{\mathrm{b} *}$ & $0.350^{\mathrm{a}}$ & $0.190^{\mathrm{b}}$ & $0.182^{\mathrm{b}}$ \\
\hline & Basal & $0.410^{\mathrm{a} *}$ & $0.310^{\mathrm{b}}$ & $0.208^{c}$ & $0.219^{c}$ \\
\hline \multirow[t]{2}{*}{ SI } & Top & $0.119^{\mathrm{a} *}$ & $0.116^{\mathrm{a} *}$ & $0.101^{\mathrm{a}}$ & $0.119^{\mathrm{a}}$ \\
\hline & Basal & $0.074^{\mathrm{c} *}$ & $0.162^{\mathrm{a} *}$ & $0.093^{c}$ & $0.119^{b}$ \\
\hline \multirow[t]{2}{*}{ RWC } & Top & $0.125^{\mathrm{a}}$ & $0.058^{\mathrm{b} *}$ & $0.111^{\mathrm{a} *}$ & $0.137^{\mathrm{a}}$ \\
\hline & Basal & $0.138^{\mathrm{a}}$ & $0.102^{\mathrm{bc} *}$ & $0.077^{c *}$ & $0.125^{\mathrm{ab}}$ \\
\hline
\end{tabular}


tion of this species to the current conditions of campo rupestre, and the extra susceptibility of this species to climate change (see Vié et al., 2009). Extrapolating these results and considering the high endemism rate and specialization of campo rupestre species (see Silveira et al., 2016), our results may presage a worrying scenario for this vegetation profile under global warming.

The shaded individuals of $A$. nudicaulis showed the highest heat tolerance among the studied groups. In fact, we found a wide variation in heat tolerance between sun-exposed and shaded individuals of this species (more than $3^{\circ} \mathrm{C}$ ). Overall, the sun-exposed individuals of $A$. nudicaulis showed similar values to Vriesea species. Regarding these differences in $A$. nudicaulis responses, the more constant conditions along days and years of shade environments seems to increase and stabilize (i.e. reduce the plasticity) the thermal tolerance of this species. These results are consistent with the findings that light conditions interact strongly with heat stress and can, at high intensity, damage the photosynthetic apparatus (Valladares and Pearcy, 1997; but see Krause et al., 2016). On the other hand, since $A$. nudicaulis is from Bromelioideae and $V$. minarum and $V$. bituminosa are from Tillandsioideae subfamily, the similar thermal tolerance observed among the last two species may be explained not only by the influence of their photosynthetic pathway (i.e. $C_{3}$ photosynthesis), but also by a phylogenetic signal, as shown by Marques et al. (2012) and Müller et al. (2016) for seed germination of bromeliads.

The low plasticity of heat tolerance found for all studied groups in this study (RDPI < 0.04) corroborated the findings of Araújo et al. (2013), which show that plants often exhibit low variability in heat tolerance. The authors suggest that this is a consequence of the limited variation in the ability of organisms to avoid the destabilizing effects of elevated temperatures on membranes and proteins, since the changes in lipid composition of membranes and the increased production of heat shock proteins are normally not enough to enable them to deal with temperatures above $45^{\circ} \mathrm{C}$. Thus, despite being small, the observed differences in $\mathrm{T}_{50}$ plasticity among tested groups are ecologically relevant for campo rupestre bromeliads.

Among the few studies providing estimates of photosynthetic heat tolerance in CAM plants, Weng and Lai (2005) - who assessed the temperature at which the minimal fluorescence $\left(\mathrm{F}_{0}\right)$ starts to increase sharply $\left(\mathrm{T}_{\mathrm{C}}\right)$ - found that the CAM bromeliad Ananas comosus showed greater heat tolerance than some $C_{3}$ and $C_{4}$ species. In another study comparing the same species to other $C_{3}$ species, $A$. comosus was again the most heat tolerant (Yamada et al., 1996). Transforming the $T_{c}$ values obtained by Weng and Lai (2005) into $\mathrm{T}_{50}$, using the equations provided by Knight and Ackerly (2003), we obtained a $\mathrm{T}_{50}$ close to $49.5^{\circ} \mathrm{C}$ for $A$. comosus. This value is quite similar to the greatest $\mathrm{T}_{50}$ values observed for $A$. nudicaulis, in the current study $\left(\mathrm{T}_{50}=50.8^{\circ} \mathrm{C}\right)$, and to previously published values of $\mathrm{C}_{3}$ species from a hot Californian desert in USA (Knight and Ackerly, 2002). In another study, based on a $T_{50}$-like index for electrolyte leakage, Didden-Zopfy and Nobel (1982) show that the CAM cactus Opuntia bigelovii, from the same Californian desert, had a $\mathrm{T}_{50}$-like index similar to the greatest values recorded by Knight and Ackerly (2002) (closed to $60^{\circ} \mathrm{C}$ ). In summary, although $A$. comosus and $A$. nudicaulis did not usually experience such high temperatures, they showed a heat tolerance similar to that of most $C_{3}$ plants native to this desert. Therefore, it is likely that CAM plants are essentially more capable of tolerating increasing temperatures, but their heat tolerance can be diminished by other environmental stresses such as sun exposure. Furthermore, the assumed greater heat tolerance of CAM plants, together with their water conservative mechanism, agree with previous assumptions that global increase in average temperature and arid areas may favor these plants (e.g. Graham and Nobel, 1996; Reyes-García and Andrade, 2009).

The negative relationship between heat tolerance and titratable acidity of shaded and sun-exposed $A$. nudicaulis was reflected in the daily variations observed for both physiological parameters during the rainy season. This relationship was reported for other CAM plants (Larcher, 1980; Lösch and Kappen, 1983; Kappen and Lösch, 1984; Krause et al., 2016) as well as for another CAM bromeliad, for which Chaves et al. (2015) showed that, under controlled conditions, leaf acidity decreases and thermal tolerance increases as temperature increases. This mechanism may have evolved due to the increase in tonoplast permeability and acid remobilization from vacuoles in response to higher temperatures (Friemert et al., 1988; Behzadipour et al., 1998; Savchenko et al., 2002; Lin et al., 2006), avoiding acid leakage during a warming event. On the other hand, in agreement with our observations for $V$. bituminosa, other studies have also reported daily variations of thermal tolerance in $C_{3}$ plants (e.g., Braun et al., 2002; Froux et al., 2004; Campos, 2011). This variation may be related to changes in sun-exposure or leaf temperature throughout the day (Braun et al., 2002; Froux et al., 2004), or may even be due to sensitivity to the water stress experienced at the hottest time of day during the dry season (see Goltsev et al., 2012; Rollins et al., 2013; Zivcak et al., 2013; Zivcak et al., 2014).

Heat tolerance was a very important variable for distinguishing the ecological strategies of the studied groups. Thus, this parameter could be used as a trait to differentiate the functional roles of plants. Furthermore, the strong correlation between both assays of heat tolerance demonstrated that the studied bromeliads do not have the thermal trade-off described for animals by Rezende et al. (2014). That is, the most tolerant bromeliad species to increasing temperature was also the one able to withstand stressful temperatures for longer periods. This lack of thermal trade-off may be common in plants, since their physiological strategies are distinct from those of animals; or it may be a consequence of the pronounced daily and annual temperature variation in campo rupestre formations (see Alves et al., 2014; Silveira et al., 2016).

Our results showed that bromeliads' ability to overcome hot temperatures, together with its plasticity, may be relevant for explaining their current distribution. In this case, the species currently restricted to the inter-glacial refuge (i.e. campo rupestre), may be more threatened by climate changes due to their lower heat tolerance and plasticity. Our study also indicated that CAM bromeliads may potentially be more heat tolerant than $C_{3}$ plants, but their heat tolerance and its plasticity are highly affected by sun exposure conditions and climate seasonality. Furthermore, our results also indicated that heat tolerance, especially the ability to withstand stressful temperatures for a long time, is an important parameter that differentiates the ecological strategies of these bromeliads species. This is the first case study evaluating the ability of campo rupestre species to overcome warming temperatures. Further investigation on this topic will certainly improve our understanding about the effects of climate change on this megadiverse ecosystem.

\section{Acknowledgment}

This work was supported by CNPq (Conselho Nacional de Desenvolvimento Científico e Tecnológico) and FAPEMIG (Fundação de Amparo à Pesquisa do Estado de Minas Gerais) Brazilian foundations.. We thank CAPES (Coordenação de Aperfeiçoamento de Pessoal de Nível Superior) for the scholarship awarded to CJNC; Santuário Nossa Senhora da Piedade staff for the research permissions and the pleasant stay during the field work; and Vincenzo Ellis, Megan King and Felipe Aoki for the English review. We also thank the anonymous reviewers of Flora journal for their insightful comments and suggestions. 


\section{Appendix A. Supplementary data}

Supplementary data associated with this article can be found, in the online version, at http://dx.doi.org/10.1016/j.flora.2017.05. 003.

\section{References}

Araújo, M.B., Ferri-Yáñez, F., Bozinovic, F., Marquet, P.A., Valladares, F., Chown, S.L., 2013. Heat freezes niche evolution. Ecol. Lett. 16, 1206-1219.

Behzadipour, M., Ratajczak, R., Faist, K., Pawlitschek, P., Trémolières, A., Kluge, M. 1998. Phenotypic adaptation of tonoplast fluidity to growth temperature in the CAM plant Kalanchoë daigremontiana Ham. et Per. is accompanied by changes in the membrane phospholipid and protein composition. J. Membr. Biol. 166, $61-70$

Benzing, D.H., 2000. Bromeliaceae: Profile of an Adaptive Radiation. Cambridge University Press, Cambridge.

Berry, J., Bjorkman, O., 1980. Photosynthetic response and adaptation to temperature in higher plants. Annu. Rev. Plant Physiol. 31, 491-543.

Bert, T.M., Luther, H.E., 2005. Aechmea Information. Florida Council of Bromeliad Societies, Sarasota, FL.

Blois, J.L., Zarnetzke, P.L., Fitzpatrick, M.C., Finnegan, S., 2013. Climate change and the past present, and future of biotic interactions. Science 341, 499-504.

Brandão, M., Gavilanes, M.L., 1990. Mais uma contribuição para o conhecimento da Cadeia do Espinhaco em Minas Gerais (Serra da Piedade) - II. Daphne 1, 26-43.

Braun, V., Buncher, O., Neuner, G., 2002. Thermotolerance of photosystem 2 of three alpine species under field conditions. Photosynthetica 40 (587-549)

Bukatsch, F., 1972. Bermerkungen zur Doppelfärbung Astrablau-Safranin. Mikrokosmos 61, 255.

Campos, P.T., 2011. Fenologia e variações sazonais no status hídrico e na termotolerância em espécies lenhosas em um fragmento de mata semidecídua em. Universidade Federal de Minas Gerais, Belo Horizonte, MG.

Carpenter, K.E., Abrar, M., Aeby, G., Aronson, R.B., Banks, S., Bruckner, A., Chiriboga, A., Cortés, J., Delbeek, J.C., Devantier, L., Edgar, G.J., Edwards, A.J., Fenner, D., Guzmán, H.M., Hoeksema, B.W., Hodgson, G., Johan, O., Licuanan, W.Y., Livingstone, S.R., Lovell, E.R., Moore, J., a Obura, D.O., Ochavillo, D., Polidoro, B. a Precht, W.F., Quibilan, M.C., Reboton, C., Richards, Z.T., Rogers, A.D., Sanciangco, J., Sheppard, A., Sheppard, C., Smith, J., Stuart, S., Turak, E., Veron, J.E.N., Wallace, C., Weil, E., Wood, E., 2008. One-third of reef-building corals face elevated extinction risk from climate change and local impacts. Science $321,560-563$.

Chaves, C.J.N., Leal, B.S.S., de Lemos-Filho, J.P., 2015. Temperature modulation of thermal tolerance of a CAM-tank bromeliad and the relationship with acid accumulation in different leaf regions. Physiol. Plant. 154, 500-510.

Christensen, J.H., Hewitson, B., Busuioc, A., Chen, A., Gao, X., Held, I., Jones, R., Kolli, R.K., Kwon, W.-T., Laprise, R., Magaña Rueda, V., Mearns, L., Menéndez, C.G., Räisänen, J., Rinke, A., Sarr, A., Whetton, P., 2007. Regional climate projections. In: Manning, M., Chen, Z., Marquis, M., Averyt, K.B., Tignor, M., Miller, H.L. (Eds.), In: Climate Change 2007: The Physical Science Basis. Contribution of Working Group I to the Fourth Assessment Report of the Intergovernmental Panel on Climate Change [Solomon, S., D. Qin. Cambridge University Press, Cambridge, United Kingdom and New York, NY USA.

dos S. Coser, T.S., 2008. Bromeliacese Juss, dos campo rupestre do Parque Estadual do Itacolomi, Minas Gerais. In: Florística e aspectos fenológicos. Universidade Federal de Viçosa, Brasil.

Crowley, T.J., North, G.R., 1987. Abrupt climate change and extinction events in earth history. Science 240, 996-1002

Cushman, J.C., Borland, A.M., 2002. Induction of Crassulacean acid metabolism by water limitation. Plant Cell Environ. 25, 295-310.

Dawson, T.P., Jackson, S.T., House, J.I., Prentice, I.C., Mace, G.M., 2011. Beyond predictions: biodiversity conservation in a changing climate. Science (80-.) 332, 53-58.

Didden-Zopfy, B., Nobel, P.S., 1982. High temperature tolerance and heat acclimation of Opuntia bigelovii. Oecologia 52,176-180

Fernandes, G.W., Barbosa, N.P.U., Negreiros, D., Paglia, A.P., 2012. Challenges for the conservation of vanishing megadiverse rupestrian grasslands. Nat. Conserv. 12, $162-165$

Forzza, R.C., Costa, A., Siqueira-Filho, J.A., Martinelli, G., Monteiro, R.F., Santos-Silva, F., Saraiva, D.P., Paixão-Souza, B., 2012. Bromeliaceae. In: Lista de Espécies da Flora do Brasil. Jardim Botânico do Rio de Janeiro [online], URL: http:// floradobrasil.jbrj.gov.br/2012/FB006431.

Friemert, V., Heininger, D., Kluge, M., Ziegler, H., 1988. Temperature effects on malic-acids efflux from the vacuoles and on the carboxylation pathways in Crassulacean-acid-metabolism plants. Planta 174, 453-461.

Friendly, M., 2007. HE plots for multivariate general linear models. J. Comput. Graph. Stat. 16, 421-444

Froux, F., Ducrey, M., Epron, D., Dreyer, E., 2004. Seasonal variations and acclimation of the thermostability of photochemistry in four mediterranean conifers. Ann. For. Sci. 61, 235-241.

Garcia, R.A., Araújo, M.B., Burgess, N.D., Foden, W.B., Gutsche, A., Rahbek, C. Cabeza, M., 2014. Matching species traits to projected threats and opportunities from climate change. J. Biogeogr. 41, 724-735.

Givnish, T., Barfuss, M.H.J., Ee, B.V., Riina, R., Schulte, K., Horres, R., Consiska, P.A., Jabaily, R.S., Crayn, D.M., Smith, A.C., Winter, K., Brown, G.K., Evans, T.M., Holst,
B.K., Luther, H., Till, W., Zizka, G., Berry, P.E., Sytsma, K.J., 2014. Adaptive radiation, correlated and contingent evolution: and net species diversification in Bromeliaceae. Mol. Phy. Evol. 71, 55-78.

Givnish, T. 2015. Adaptive radiation versus radiation and explosive diversification: why conceptual distinctions are fundamental to understanding evolution. New Phytol. 207, 297-303.

Godoy, O., de Lemos-Filho, J.P., Valladares, F., 2011. Invasive species can handle higher leaf temperature under water stress than mediterranean natives. Environ. Exp. Bot. 71, 207-214.

Goltsev, V., Zaharieva, I., Chernev, P., Kouzmanova, M., Kalaji, H.M., Yordanov, I., Krasteva, V., Alexandrov, V., Stefanov, D., Allakhverdiev, S.I., Strasser, R.J., 2012 Drought-induced modifications of photosynthetic electron transport in intact leaves: analysis and use of neural networks as a tool for a rapid non-invasive estimation. Biochim. Biophys. Acta 1817, 1490-1498.

Graham, E.A., Nobel, P.S., 1996. Long-term effects of a doubled atmospheric CO2 concentration on the CAM species Agave deserti. J. Exp. Bot. 47, 61-69.

Hartsock, T.L., Nobel, P.S., 1976. Watering converts a CAM plant to daytime $\mathrm{CO}_{2}$ uptake. Nature 262, 574-576.

Hüve, K., Bichele, I., Rasulov, B., Niinemets, Ü., 2011. When it is too hot for photosynthesis Heat-induced instability of photosynthesis in relation to respiratory burst, cell permeability changes and $\mathrm{H}_{2} \mathrm{O}_{2}$ formation. Plant Cell Environ. 34, 113-126.

Holt, R.D., 1990. The microevolutionary consequences of climate change. Trends Ecol. Evol. 5, 311-315.

IPCC, 2007. Summary for policymakers. In: Parry, M.L, Canzianik, O.F., Palutikof, J.P., van der Linden, P.J., Hanson, C.E. (Eds.), Climate Change 2007: Impacts, Adaptation and Vulnerability. Contribution OfWorking Group II to the Fourth Assessment Report of the Intergovernmental Panel on Climate Change. Cambridge University Press, Cambridge UK, pp. 7-22.

IPCC, 2012. Managing the Risks of Extreme Events and Disasters to Advance Climate Change Adaptation. A Special Report of Working Groups I and II of the Intergovernmental Panel on Climate Change. Cambridge University Press, Cambridge, UK and New York, USA.

IPCC, et al., 2014. Summary for policymakers. In: Field, C.B., Barros, V.R., Dokken, D.J. (Eds.), Climate Change 2014: Impacts, Adaptation, and Vulnerability. Part A: Global and Sectoral Aspects. Contribution of Working Group II to the Fifth Assessment Report of the Intergovernmental Panel on Climate Change. Cambridge University Press, Cambridge, pp. 1-32.

Johansen, D.A., 1940. Plant Microtechnique. McGraw-Hill Book Co., New York.

Kappen, L., Lösch, R., 1984. Diurnal patterns of heat tolerance in relation to CAM. Zeitschrift für Pflanzenphysiologie 114, 87-96

Kenny, D.A., Hoyt, W., 2009. Multiple levels of analysis in psychotherapy research. Psychother. Res. 19, 462-468.

Knight, C.A., Ackerly, D.D., 2002. An ecological and evolutionary analysis of photosynthetic thermotolerance using the temperature-dependent increase in fluorescence. Oecologia 130, 505-514.

Knight, C.A., Ackerly, D.D., 2003. Evolution and plasticity of photosynthetic thermal tolerance: specific leaf area and leaf size: congeneric species from desert and coastal environments. New Phytol. 160, 337-347.

Kraus, J.E., Arduin, M., 1997. Manual básico de métodos em morfologia vegetal. Editora da Universidade Federal Rural do Rio de Janeiro, Seropédica, Rio de Janeiro.

Krause, G.H., Winter, K., Krause, B., Virgo, A., 2016. Protection by light against heat stress in leaves of tropical crassulacean acid metabolism plants containing high acid levels. Funct. Plant Biol. 43, 1061-1069.

Lösch, R., Kappen, L., 1983. Die temperaturresistenz makaronesischer Sempervivoidae. Verhandlungen der Geselshaft für Ökologie 10, 521-528.

Larcher, W., 1980. Klimastreß im Gebirge - Adaptationstraining und selektionsfilter für pflanzen. Rheinisch-Westf, vol. 291. Akad. Wiss, Vorträge N, pp. 49-78.

Lin, Q., Abe, S., Nose, A., Sunami, A., Kawamitsu, Y., 2006. Effects of high night temperature on Crassulacean Acid Metabolism (CAM) photosynthesis of Kalanchoë pinnata and Ananas comosus. Plant Prod. Sci. 9, 10-19.

Müller, L.-L.B., Albach, D.C., Zotz, G., 2016. Are $3{ }^{\circ} \mathrm{C}$ too much? - Thermal niche breadth in Bromeliaceae and global warming. J. Ecol.

Malcolm, J.R., Liu, C., Neilson, R.P., Hansen, L., Hannah, L., 2006. Global warming and extinctions of endemic species from biodiversity hotspots. Conserv. Biol. 20, 538-548.

Marques, A.R., Lemos-Filho, J.P.de, 2008. Fenologia reprodutiva de espécies de bromélias na Serra da Piedade, MG, Brasil. Acta Bot. Bras. 22, 417-424.

Marques, A.R., Lemos-Filho, J.P., de Mota, R.C., 2012. Diversity and conservation status of bromeliads from Serra da Piedade Minas Gerais, Brazil. Rodriguésia 63, 243-255.

Mercier, H., Freschi, L., 2008. Flora epifítica de florestas tropicais: uma análise fisiológica sobre possíveis impactos causados pelas mudanças climáticas. In: Buckeridge, M.S. (Ed.), Biologica \& Mudanças Climáticas No Brasil. RiMa Editora, São Carlos, Brasil, pp. 93-100.

Nobel, P.S., 1988. Environmental Biology of Agaves and Cacti. Cambridge University Press, New York.

Ogburn, R.M., Edwards, E.J., 2010. The ecological water-use strategies of succulent plants. Adv. Bot. Res. 55, 179-225.

Ogburn, R.M., Edwards, E.J., 2012. Quantifying succulence: a rapid, physiologically meaningful metric of plant water storage. Plant. Cell Environ. 35, 1533-1542.

Osmond, B., Neales, T., Stange, G., 2008. Curiosity and context revisited: crassulacean acid metabolism in the Anthropocene. J. Exp. Bot. 59, 1489-1502. 
Palma-Silva, C., Leal, B.S.S., Chaves, C.J.N., Fay, M.F., 2016. Advances in and perspectives on evolution in Bromeliaceae. Bot. J. Linn. Soc. 181, 305-322.

Parmesan, C., Hanley, M.E., 2015. Plants and climate change: complexities and surprises. Ann. Bot. 116, 849-864.

Parmesan, C., Yohe, G., 2003. A globally coherent fingerprint of climate change impacts across natural systems. Nature 421, 37-42.

Parmesan, C., 2006. Ecological and evolutionary responses to recent climate change. Annu. Rev. Ecol. Evol. Syst. 37, 637-669.

Pecl, G.T., Araújo, M.B., Bell, J.D., Blachard, J., Bonebrake, T.C., Chen, I.-C., Clark, T.D., Colwell, R.K., Danielsen, F., Evengard, B., Falconi, L., Ferrier, S., Frusher, S., Garcia, R.A., Griffis, R.B., j, Hobday A., Janion-Scheepers, C., Jarzyna, M.A., Jennings, S., Lenoir, J., Linnetved, H.I., Martin, V.Y., McCormak, P.C., McDonald, J., Mitchell, N.J., Mustonen, T., Pandolfi, J.M., Pettorelli, N., Popova, E., Robinson, S.A., Scheffers, B.R., Shaw, J.D., Sorte, C.J.B., Strugnell, J.M., Sunday, J.M., Tuanmu, M.-N., Vergés, A., Villanueva, C., Wernberg, T., Wapstra, E., Williams, S.E., 2017. Biodiversity redistribution under climate change: impacts on ecosystems and human well-being. Science 355, eaai9214.

R Core Team, 2014. R: A Language and Environment for Statistical Computing.

Reyes-García, C., Andrade, J.L., 2009. Crassulacean acid metabolism under global climate change. New Phytol. 181, 754-757.

Rezende, E.L., Castañeda, L.E., Santos, M., 2014. Tolerance landscapes in thermal ecology. Funct. Ecol. 28, 799-809.

Rollins, J.A., Habte, E., Templer, S.E., Colby, T., Schmidt, J., von Korff, M., 2013. Leaf proteome alterations in the context of physiological and morphological responses to drought and heat stress in barley (Hordeum vulgare L.). J. Exp. Bot. 64, 3201-3212.

Root, T.L., Price, J.T., Hall, K.R., Schneider, S.H., Rosenzweig, C., Pounds, A., 2003. Fingerprints of global warming on wild animals and plants. Nature 421 57-60.

Rosenzweig, C., Karoly, D., Vicarelli, M., Neofotis, P., Wu, Q., Casassa, G., Menzel, A., Root, T.L., Estrella, N., Seguin, B., Tryjanowski, P., Liu, C., Rawlins, S., Imeson, A., 2008. Attributing physical and biological impacts to anthropogenic climate change. Nature 453, 353-357, http://dx.doi.org/10.1038/nature06937.

Rull, V., 2009. Microrefugia. J. Biogeogr. 36, 481-484.

Savchenko, G.E., Klyuchareva, E.A., Abramchik, L.M., Serdyuchenko, E.V., 2002. Effect of periodic heat shock on the inner membrane system of etioplasts. Russ. J. Plant Physiol. 49, 349-359.

Silveira, F.A.O., Negreiros, D., Barbosa, N.P.U., Buisson, E., Carmo, F.F., Carstensen, D.W., Conceição, A.a., Cornelissen, T.G., Echternacht, L., Fernandes, G.W. Garcia, Q.S., Guerra, T.J., Jacobi, C.M., Lemos-Filho, J.P., Le Stradic, S., Morellato, L.P.C., Neves, F.S., Oliveira, R.S., Schaefer, C.E., Viana, P.L., Lambers, H., 2016. Ecology and evolution of plant diversity in the endangered campo rupestre: a neglected conservation priority. Plant Soil 403, 1-24.

Silvestro, D., Zizka, G., Schulte, K., 2014. Disentangling the effects of key innovations on the diversification of Bromelioideae (Bromeliaceae). Evolution 68, 163-175.

Smith, L.B., Downs, R.J., 1979. Bromelioideae (Bromeliaceae). Flora Neotrop. 14, 1493-2142.

Stewart, J.R., Lister, A.M., Barnes, I., Dalén, L., 2010. Refugia revisited: individualistic responses of species in space and time. Proc. Biol. Sci. 277, 661-671.
Thuiller, W., Lavorel, S., Araújo, M.B., 2005. Niche properties and geographical extent as predictors of species sensitivity to climate change. Glob. Ecol. Biogeogr. 14, 347-357, http://dx.doi.org/10.1111/j.1466-822X.2005.00162.x.

Valladares, F. Pearcy, R.W., 1997. Interactions between water stress, sun-shade acclimation, heat tolerance and photoinhibition in the sclerophyll Heteromeles arbutifolia. Plant Cell Environ. 20, 25-36

Valladares, F., Sanchez-Gomez, D., Zavala, M.A., 2006. Quantitative estimation of phenotypic plasticity: bridging the gap between the evolutionary concept and its ecological applications. J. Ecol. 94, 1103-1116.

de M. Versieux, L., Wendt, T., Louzada, R.B., Wanderley, M.D.G.L., 2008 Bromeliaceae da Cadeia do Espinhaço. Megadiversidade 4, 98-110.

Vié, Jean-Christophe, Craig, Hilton-Taylor, Stuart, Simon N. (Eds.), 2009. Wildlife in a Changing World: an Analysis Ofthe 2008 IUCN Red List of Threatened Species. IUCN.

Wagenmakers, E.-J., Farrell, S., 2004. AIC model selection using Akaike weights. Psychon. Bull. Rev. 11, 192-196.

Weigelt, P., Steinbauer, M.J., Cabral, J.S., Kreft, H., 2016. Late Quaternary climate change shapes island biodiversity. Nature 532, 99-102.

Weng, J., Lai, M., 2005. Estimating heat tolerance among plant species by two chlorophyll fluorescence parameters. Photosynthetica 43, 439-444.

Went, F.W., 1953. The effect of temperature on plant growth. Annu. Rev. Plant Physiol. 4, 347-362.

Yamada, M., Hidaka, T., Fukamachi, H., 1996. Heat tolerance in leaves of tropical fruit crops as measured by chlorophyll fluorescence. Sci. Hortic. (Amsterdam) 67, 39-48.

Yamane, Y., Shikanai, T., Kashino, Y., Koike, H., Satoh, K., 2000. Reduction of $Q_{A}$ in the dark: another cause of fluorescence $\mathrm{F}_{\mathrm{O}}$ increases by high temperatures in higher plants. Photosynth. Res. 63, 23-34.

Yamori, W., Hikosaka, K., Way, D.A., 2014a. Temperature response of photosynthesis in C3, C4, and CAM plants: temperature acclimation and temperature adaptation. Photosynth. Res. 119, 101-117.

Yamori, W., Hikosaka, K., Way, D.A., 2014b. Temperature response of photosynthesis in $C_{3}, C_{4}$, and CAM plants: temperature acclimation and temperature adaptation. Photosynth. Res. 119, 101-117.

Zhang, J.-L., Poorter, L., Hao, G.-Y., Cao, K.-F., 2012. Photosynthetic thermotolerance of woody savanna species in China is correlated with leaf life span. Ann. Bot. 1027-1033.

Zivcak, M., Brestic, M., Balatova, Z., Drevenakova, P., Olsovska, K., Kalaji, H.M., Yang, X., Allakhverdiev, S.I., 2013. Photosynthetic electron transport and specific photoprotective responses in wheat leaves under drought stress. Photosynth. Res. 117, 529-546.

Zivcak, M., Brestic, M., Kalaji, H.M., Govindjee, 2014. Photosynthetic responses of sun- and shade-grown barley leaves to high light: is the lower PSII connectivity in shade leaves associated with protection against excess of light? Photosynth. Res. 119, 339-354. 